
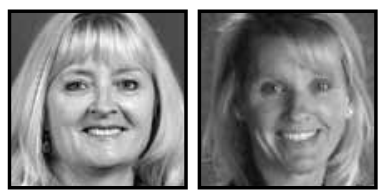

\title{
ImMEDIAte Gratification: Examining the Use of Digital Media in Adolescents' In-School and Out-of-School Lives
}

\author{
Janette Hughes and Stephanie Thompson, \\ University of Ontario Institute of Technology
}

\begin{abstract}
Using a mixed method research approach of qualitative case study analysis and quantitative surveying, this research ${ }^{1}$ investigates the development of adolescent digital literacies and their use of mobile devices to further their understandings. More specifically, this article focuses on how a class of adolescents, ages 12-13, reflected on the impact of digital technologies and media on their lives while immersed in a rich media setting, using a social networking site and a combination of their own mobile devices and tablets that were provided to them by their classroom teacher.
\end{abstract}

hrough the immersive use of personal mobile devices such as smart
phones, tablets, and traditional laptops and desktop computers, ado-
lescents inhabit an out-of-school world of burgeoning new media. Their lives are marked by extensive access to and engagement with, (a) a growing abundance of multimodal texts in digital form, and (b) a wide variety of robust communication and social networking digital tools, which inevitably help shape their digital literacy skills and their personal and community identities. At the same time, there has been a marked reluctance in educational settings to allow students to use their personal mobile devices and the new media they typically engage with, thus creating a disconnect between school and out-of-school experiences.

Using a multiliteracies pedagogy, mobile devices and social networking platforms can give students voice and agency in the context of their learning 
communities, and thus provide opportunities for them not only to learn subject matter but also to explore issues of identity and their place in the world around them. Using a mixed method research approach of qualitative case study analysis and quantitative surveying, this research investigates the relationship between a multiliteracies pedagogy and the development of adolescent digital literacy and identity. In this research we are interested in how adolescents perceive the impact of digital technology and media on their lives, as they examine the underlying messages of various media forms, as well as how ubiquitous access to mobile devices and tablets can potentially transform teaching and learning literacy practices. More specifically, this paper focuses on the case study of one 12-year-old girl, reflecting on the impact of digital technologies and media on her life while immersed in a rich media setting, using a combination of her own mobile devices and a tablet that was provided to her by her classroom teacher.

The research project in general explores the intersection of adolescents' out-of-school new media experiences with digital literacy education, in a classroom setting in Ontario, Canada. The student participants read, viewed, and discussed several texts, both print-based and multimodal, and used a social networking site (Ning) ${ }^{2}$ to respond to these texts that focused on the role of new media in adolescents' lives. The research capitalizes on students' nascent digital literacy skills through the use of mobile devices and tablets and builds classroom-based research knowledge in the rapidly growing field of digital literacies. Adolescent lives include the abundant use of digital texts, making it necessary to redefine or reconsider our literacy and learning practices, including our pedagogical choices. Traditional print resources such as reference books, novels, and text books have been staple tools to help provide knowledge for student learners for many generations; the reality, however, is that the cadre of technology present in the average North American home far exceeds the technological resources of a school's classroom or computer labs. Realistically, with students sharing a handful of desktop machines, and with every teacher in the school vying for time in the computer lab, these are not a viable option for regular and consistent student access to digital learning. Mobile devices, with their portability, wide range of resources, immediacy of content and their clear, visual interfaces offer exciting possibilities for student learners. Social networking tools, which are already a big part of adolescents' digital lives, are increasingly used by organizations and educational institutions to provide information, to communicate with customers and students, and to offer educational service. In this context, we make extensive use of the social networking tool Ning, accessed through mobile devices. The Ning is a safe, secure environment that has similar affordances to Facebook. 


\section{Theoretical Framework}

\section{Multiliteracies}

Within a multiliteracies framework there is an emphasis on students as producers or "Designers" rather than just consumers of text (Cope \& Kalantzis, 2000). The New London Group's (1996) concept of multiliteracies highlights the relevance of new forms of literacy associated with emerging multimedia, multimodal technologies. From our experience in schools, teachers are increasingly aware of and attracted to the educational potential of new media devices and web-based tools, especially as the conventional notion of literacy in curriculum has shifted to reflect a multiplicity of literacies. Although institutional obstacles prevent most teachers from taking advantage of this potential, school districts are starting to address this issue. The idea of multiliteracies (New London Group, 1996) is theoretically grounded in the sociocultural tradition, which views literacy not as something you have that is functional and autonomous, but rather as a series of social practices (Harste, 2003) inferred from events and mediated by texts. The traditional view of literacy and the reading and writing of print text has expanded to include viewing and communicating in many different ways, about texts of all kinds, including images, video, music, and sounds, gestures, and more. New literacies, as defined by Lankshear and Knobel (2007), are not characterized solely by their digital or technical features. They also involve a new mindset or a new ethos that focuses on participation, collaboration, and distribution (Lankshear \& Knobel, 2007). Digital tools have increasingly become tools of mediation and communication and many facilitate the kinds of sharing that are conducive to literacy education ideals. Contemporary social interaction is characterized by changes in the materiality of texts as well as changes in the ways we make meaning. Kress and Van Leeuwen (2001) suggest that in a digital environment, "meaning is made in many different ways, always, in the many different modes and media which are co-present in a communicational ensemble" (p. 111). Jones and Hafner (2012) argue that digital media offer new ways of doing different kinds of things, making different kinds of meanings, relating in different ways with those around us, thinking about things differently and being in different ways, that is, the kinds of social identities we can perform or adopt. Weber and Mitchell's (2008) notion of identity as "personal and social bricolage" views identity construction as "an evolving active construction that constantly sheds bits and adds bits, changing through dialectical interactions with the digital and non-digital world, involving physical, psychological, social, and cultural agents" (p. 43). The rapid adoption of new technologies and the social networking platforms that have become ever easier to access has implications for the adolescents who use them. 
We borrow the notion of "multitextured" teaching from Beach, Appleman, Hynds, and Wilhelm (2011), which advocates (1) using multiple texts, including print literature, but also a wide variety of digital texts and (2) using these texts to read critically against the texts of their own lives. The authors explain, "in the process of viewing literary texts against a backdrop of other popular and canonical texts, teenagers can begin to move more critically through the 'identity crises' that Erikson talks about" (p. 34). As Beach et al. suggest, it is not about walking away from literacy practices that we know work; however, it is becoming increasingly important to better understand how adolescents, who have grown up in a digital age, use and interact with digital media in the context of their literacy practices.

\section{Communities of Practice}

Although adolescents use their mobile devices to access information anytime, anywhere, they use them primarily to get and stay connected. Collaborative knowledge construction is one of the oft-cited benefits of online learning, but in order for effective learning to take place instructors must foster and develop an "affinity space" (Gee, 2004) or "community of practice" (Wenger, 1998, 2000, 2007). Gee (2004) describes affinity spaces as "specially designed spaces (physical and virtual) constructed to resource people [who are] tied together ... by a shared interest or endeavour ..." (p. 73). Wenger $(1998,2000,2007)$ has coined the phrase "communities of practice," which he describes as groups of people who share a concern, passion, or interest for something they do and learn to do it better as they interact regularly. Anderson (2001) suggests that "[i]nformal sharing of experiences is often the most valuable result for groups of [individuals] engaged in formal education, and it is likely that it constitutes a significant enhancement to ... education" (p. 32). Social networking sites position users as co-authors and co-developers and tap into their collective intelligence. They are constructed to facilitate the collection and sharing of usergenerated content. A social networking network (such as Ning) fits within the social constructivist paradigm that views the building of new knowledge as a social and collaborative enterprise. We extend Wenger's $(1998,2009)$ notion of communities of practice to school and classroom communities that use an inquiry approach as they strive to have students see themselves within a larger world and what that means within a diverse society. As learners develop socially, cognitively, and emotionally, it is necessary that they understand that everyone has rights and responsibilities within a given community. No longer is the curriculum simply the novel or the facts to be learned but, rather, the students and their teacher together using books, other authentic resources, and their own opinions and experiences to create the "living curriculum" as a true community of learners (Connelly \& Clandinin, 2006). 


\section{Methodology}

A case study approach was used to collect in-depth data related to how the students engaged with the learning material through mobile devices. Although we used pre- and post-project surveys to find out what kinds of digital technologies the students were using both at home and school, the bulk of the study is qualitative in nature, in keeping with the established practice of in-depth studies of classroombased learning and case studies in general (Stake, 2000). As Bruce (2009) points out, case studies "provide the best articulation of adolescents' media literacy processes, especially as much of the emergent forms of their use has not been studied" (p. 302). The case study method is also appropriate for studying a "bounded system" (that is, the thoughts and actions of participating students or the learning-community connection of a particular education setting) so as to understand it as it functions under natural conditions (Stake, 2000). Individual students, and their digital texts, were considered as individual cases. We examined all of the data for each individual student, and in the analysis of the authoring of the digital texts, we were particularly interested in moments that might be interpreted as "turning points" (Bruner, 1994) in the representation of identity and/or the conceptual understanding of the impact of new media on adolescents' lives.

\section{Setting for the study.}

The study involved one class of 24 middle school students, ages 12-13. The students read and critiqued a variety of texts, both print-based and digital, all of which focused on adolescent issues related to the role of new media in adolescents' lives. They participated in literature circles that focused on the following novels: Speak by Laurie Halse Anderson, Divergent and Insurgent by Veronica Roth, Dear Jo by Christina Kilbourne, Stargirl by Jerry Spinelli, and the Uglies series by Scott Westerfeld. They also examined online texts such as "It's a Book," by Lane Smith, which is a social commentary on the digital age, and a National Film Board documentary called "The Colour of Beauty," which chronicles the experiences of a young black model as she struggles to break into a profession which traditionally favours Caucasian women.

They responded to these texts and shared their opinions during face-toface meetings with their peers and teachers in organized discussion groups, as well as online on a social networking site (Ning). They also created their own digital and multimodal texts to be shared with a wider community as a way of presenting themselves and communicating about things that concern them related to their own identities. For example, they deconstructed advertisements and then developed their own online magazines or e-zines with a "healthy living" focus. They created and 
presented word clouds using Tagxedo and Wordle to convey their thoughts about body image and the media. They created digital poetry related to the theme of body image. They shared their work in a variety of venues, including on blogs which are housed on the class Ning, on the project website and through a dramatic production they scripted themselves. This took the form of a mock broadcast of a TV talk show containing song performances, advertisements, and interviews with each other on the effects of media on body image. For the purposes of this paper we focus on one specific case-Gigi (a pseudonym)-and her survey responses, comments on the Ning, digital magazine, and digital poem.

\section{Data collection and analysis.}

The qualitative research makes use of a case study methodology which includes detailed field notes, students' writing and contributions to the social networking site (Ning), transcribed interviews with students and teachers, the digital and multimodal texts created by students, and video recordings of selected learning/ authoring activities. We elicited information regarding attitudes towards issues associated with the impact of new media on their lives primarily through writing prompts using a Ning forum. For the purposes of this paper we draw on data from one student's survey responses, her written reflections on the class Ning, and her oral presentations to the class based on her creation of a digital magazine and a digital poem.

Analysis of the data required several different layers of coding and interpretation. In the first stage the bulk of the data was coded for various themes that emerged. We coded the Ning transcripts following traditional coding procedures (Strauss \& Corbin, 1990). The multimodal texts created by the student were also analyzed within a framework of semiotic meta-functions (Kress \& Van Leeuwen, 2001; Jewitt, 2008; Burn, 2008), which considers design and production as representational, interactive, and textual. Because of the complex blending of multimodal data elements, we also used the digital visual literacy analysis method of developing a "pictorial and textual representation of those elements" (Hull \& Katz, 2006, p. 41); that is, juxtaposing columns of the written text, the images from digital texts, and data from interviews, field notes and video recordings to facilitate the "qualitative analysis of patterns" (p. 41). Our analysis focused on the various modes of expression (i.e., visual image, gesture, movement) and how these work in concert to create meaning. 


\section{Findings and Discussion}

Overall we noticed a marked increase in the level of students' engagement when they used technology to access media sources and create their own digital products. The ubiquitous access to current media texts provided both immediacy and relevance in their learning and they further developed their research skills as a result of the constant access to information at their fingertips through the use of the tablets. In terms of their digital literacy skills, the students made gains in their understanding of how to use a variety of digital media software applications and hardware devices, in their ability to critically understand digital media content and applications, and in their knowledge and capacity to create their own digital texts with digital media. Their teacher also noted that there was improved collaboration as students shared resources and roles in project work. Through informal comments made in class and on the post-project survey administered to all of the students, they reported feeling "privileged" to be given an opportunity to participate in the use of devices in the classroom. Most notably, however, students demonstrated gains in the development of their critical literacy skills. To support some of these claims, we take a closer look at "Gigi's" case, which follows below, as a representative example of how one student became more critical in this technology-rich environment. Gigi's case is not atypical. We selected her as a focus for this case study, because as a committed athlete she took a special interest in the topic of body image and healthy living. She was not the top student in the class academically, nor was she the strongest writer.

\section{Gigi's Case}

\section{The surveys and the Ning.}

Gigi was described by her teacher as a

12-year-old Grade 7 student who is conscientious to the point of perfectionism, intrinsically motivated and very driven. Her personality and identity require her to strive to do her utmost in all pursuits, academic, social, and athletic. She is a staunchly loyal friend, defender of the bullied, and sincerely and deeply empathetic to those who are in distress.

Gigi described herself on the class Ning as an optimistic person:

I think that I am optimistic because I try to never let anything get me down. It is difficult to stay positive when things just aren't going your way in life 
and it feels like the whole world is against you. However, I always try my best. I try to cheer up not only myself, but my friends and peers as well. I have a lot of chances to be optimistic because I play a lot of sports. When your team is losing you can't give up or you will never get the points back. I think that is where I shine most in optimism. I will admit that when it comes to school work, it is harder for me to be positive if I am having trouble or I don't understand, however I still work at being optimistic and I think that it is important to always try.

Gigi also confirmed her teacher's description of her perfectionism when she talks about what she believes is her "weakest trait":

I think the trait that I am least likely to be known for is courage. The reason for this is because I get nervous very easily and tend to shy away when I feel intimidated. I feel like I get nervous because I like to do things perfectly and I get VERY scared that I will mess up. I think that I can change this by being more open to mistakes and try to learn from them rather than let them bother me! I think if I were to build up my courage I would do better in school because I would take more chances instead of not trying because I'm scared of messing up.

The lack of confidence that Gigi demonstrates in the previous Ning post may also have been at play when she wrote about whether she preferred to write journal entries with pen and paper or on a class social networking site, in this case the class Ning. In the pre-project survey students were asked how they felt about the prospect of writing their journals online and Gigi responded:

I don't really mind because sometimes I enjoy writing things out by hand, partly because it is fun, but also because I like to upkeep my penmanship skills. It is also nice because in a journal your thoughts and ideas aren't public and aren't there for the judging of other people. However, I also really like to use technology and to type. I work faster when I type as well which sometimes can be beneficial.

Although she clearly states that there are benefits to both traditional pen and paper journals and online journals, the thought of having her work "judged" by others seems to intimidate her. In the post-project survey that was administered five months later however, Gigi clearly indicates that she preferred writing her journal on the Ning: 
I really liked using the Ning a lot. I though it was very easy to use and follow and definitely preferred it over using a paper journal because I think that it is much easier to receive feedback (positive or negative) when it is posted for everybody to see. I enjoyed getting the feedback and/or questions about my responses because I am always looking for ways to improve my writing and the inquiries I got from other people really challenged me to think about what I was writing and helped understand some of the things that I didn't include, but should have.

The Ning certainly became a place where students could get immediate feedback on their writing from their peers and often their teacher, but it was also a forum for discussion and reflection. For example, their teacher asked them to read an article and then consider how technology and the Internet specifically impacted their lives in positive and negative ways. Gigi wrote:

Like most teens or pre-teens, I do use technology for fun, I e-mail, I go on YouTube to watch videos and I play games, I have a gaming system and a camera and all that great stuff that I love! However, technology also comes as a great benefit when I'm doing school work. Even though there are a lot of websites that can give you faulty information on the internet, there are also plenty of legitimate websites with very accurate facts. So, I guess that I am saying, technology is a big part of my life! But, I don't let technology take over my entire life. I am very physical in and outside of school. I play soccer all year, I also love to read. So in my case technology is just a bonus in my life. I had a choice and still have a choice. I can decide whether or not I want technology to control me. I choose no.

As an avid reader, Gigi also reflected on the future of "the book" in a digital age. She did not seem to be overly distressed by the idea that print books would "become a thing of the past" and seemed to accept the advent of the e-reader for her own reading.

I think that the idea of books becoming "extinct" is definitely a possibility. My reason for saying this is that right now it is basically our digital immigrants that [are] fighting to keep books around and popular. However our society continues to adapt at the same time and the gap between the number of digital natives and digital immigrants is quickly growing. At some point we will be a world filled with digital natives, as they are all being born into the world of technology. With our society moving further and further 
away from books and closer to new technology it is more likely that at some point books will become a thing of the past.

Interestingly, some of the students in this project were using Kobo on the tablets to read some of the books that were chosen for literature circles in the classroom but Gigi did not comment on this experience in her Ning responses.

\section{Deconstructing Media Advertisements and Creation of Digital Magazines}

To be digitally literate, Selber (2004) argues that students have to be proficient in the use of digital technologies but they also need to be producers of their own digital texts. He also suggests that students need to be critically aware of how and why technology is used. Selber describes students who have critical literacy as "informed questioners of technology" who can "question [computers'] designs, or challenge the grand narratives in which computers are implicated," and who become "empowered knowledge workers" (pp. 74-75). We wanted the students to be users, critics, and producers of digital media and to that end, we asked them to deconstruct online ads and then create their own e-zines in response to what they had learned by producing a magazine that promoted healthy living rather than the unrealistic expectations of beauty and lifestyle projected by the media.

Before beginning work on their own digital magazines, the students deconstructed the media messages found in current commercials. Working with a partner, Gigi chose to analyze a television commercial for Dior J'Adore featuring Charlize Theron. She was able to articulate the subtleties in the ad that serve to contribute to negative body image and she discussed the ways in which the use of colour, light, and music create an atmosphere of strength and confidence. She commented, "We interpret it as confidence ... She's doing it just for herself ... which makes the perfume more appealing." She and her partner compared this ad with the commercial for Taylor Swift's perfume, Wonderstruck, which is much more romantic and features a potential love interest in the background. They were able to comment on the underlying messages of both ads and were able to comment on the differences. After deconstructing their own ads and listening to their peers explain the media messages in their ads as well, the students felt that they now looked at ads even outside of school with a "more critical eye" than average consumers, and even their parents. 
Working in groups of approximately five, the students created digital magazines that included their own ads. The student-created ads used media to shift the focus from "unattainable perfection" to "healthy living." Gigi's group created a digital magazine that featured healthy food, an active lifestyle, and a realistic attitude toward body image (see Figures 1 and 2).

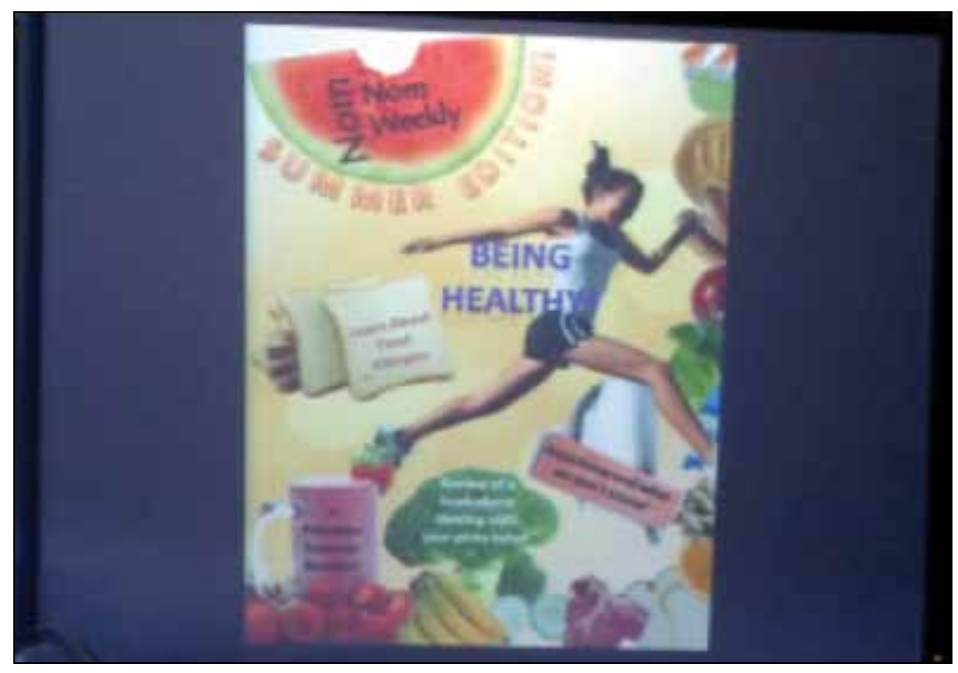

Fig. 1: Digital magazine cover page

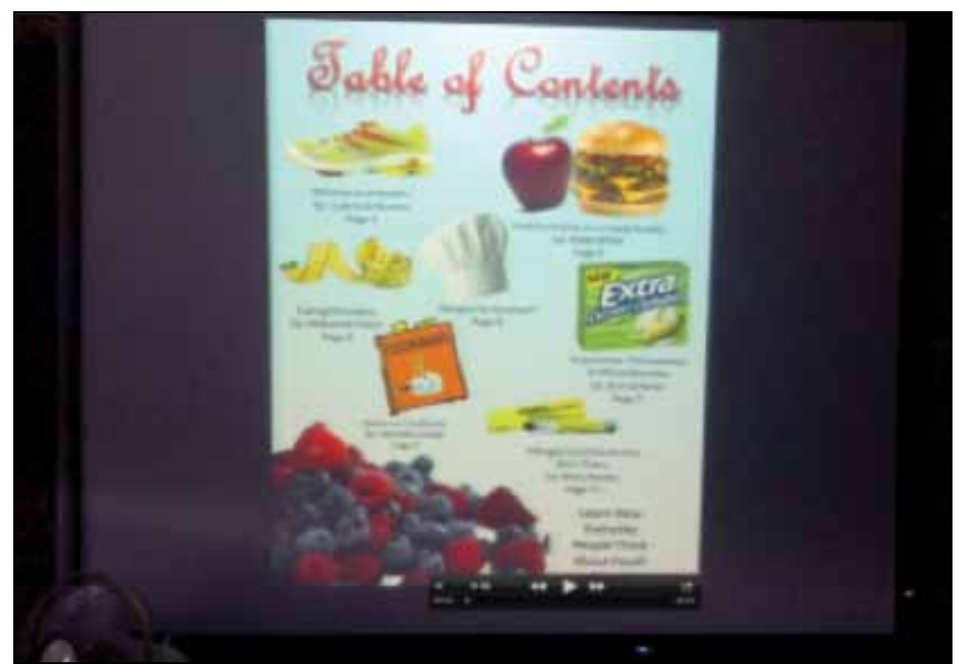

Fig. 2: Digital magazine table of contents 
There was a great deal of evidence of critical thought in the creation and subsequent presentation of the digital magazines to the rest of the class. In followup discussions, students talked about their new awareness of pervasive negative messages in media and the harmful effects these can have on adolescents. In their magazines they chose positive body-image models such as Adele to demonstrate importance of health over extreme thinness. They made comments such as:

Hopefully after reading this magazine, kids who struggle with their body image will learn to love their bodies, and even if they can't, try to improve themselves to be healthy and happy, naturally and without harming themselves.

When you start to think positively of yourself, you won't feel the need to change or even harm yourself to become your "ideal."

Gigi was able to articulate the importance of this experience to her own learning. She felt that the creation of the magazine would help students decode the media messages found in advertising and serve to promote a healthier attitude toward food. In an article she wrote for the digital magazine, she focused on the importance of healthy eating when participating in sports and how good food would contribute to better performance. She also noted how creating the magazine in a digital format enabled her group to produce a high-quality magazine. In her postproject survey, Gigi commented:

I really enjoyed creating the digital magazine because I thought that it was taking something that was fairly basic and bring it to the next level by using technology as our resource to create it. On the computer there are many more options to make your magazine advanced (i.e., videos, animations, and a wide range of design options.)

\section{The Digital Poems}

The digital poems very clearly demonstrated the students' ability to deconstruct the media's messages. Gigi worked independently to create a poem that brings multiple modes of expression (i.e., visual, gestural, linguistic, spatial, aural) together to make meaning. She used strong, graphic images to warn her peers about negative media messages (see Figure 3) and she was able to communicate the reasons for all of her design choices in a presentation of her poem to the class. She discussed the use of fonts, images, music, and word choice in a way that demonstrated her 
understanding of how each element contributes to the overall message. It is beyond the scope of this paper to elucidate all of Gigi's design choices, but here we give some representative examples.

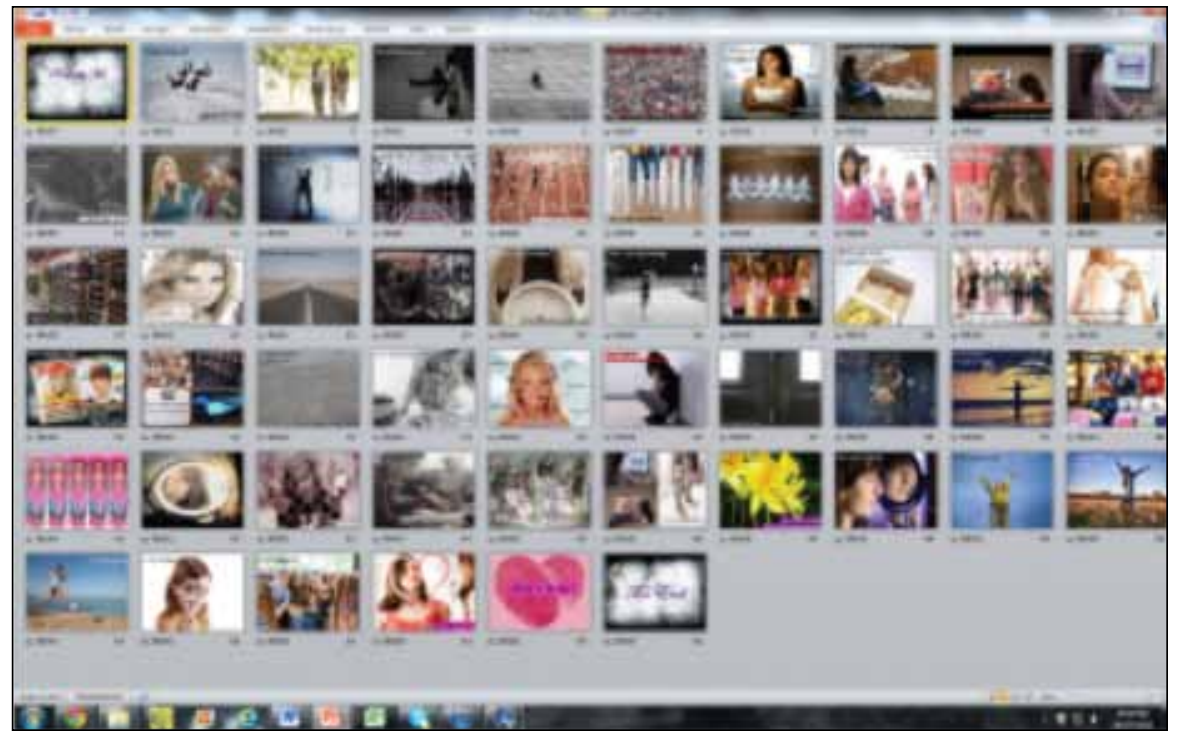

Fig. 3: Gigi's digital poem (slide sorter view)

Gigi let her digital poem play through for the class first and then restarted the video to begin her explication. The soundtrack for her poem is "Beautiful" by Christina Aguilera and the images are timed to coincide with the length of the song. Gigi began by explaining her choice to use fonts that look like handwriting. She comments, "This is someone telling their own story so I wanted the font to look like someone was writing it-it's more personable." She explains that the poem is "about loving who you are" and says she was striving for a "sense of solemnness" in the poem, which required her to "dull down" the colours in the images (most of which are taken from the Internet). She used several images of young girls putting on makeup and dressing up and commented, "I didn't want to glamorize things like this. I didn't want to make them seem like these amazing things that should be bright and happy because it's kind of looking at them negatively." Gigi argued, "people's images of themselves have been so messed with" by the media and this is reflected in her choice of the image in Figure 4. 


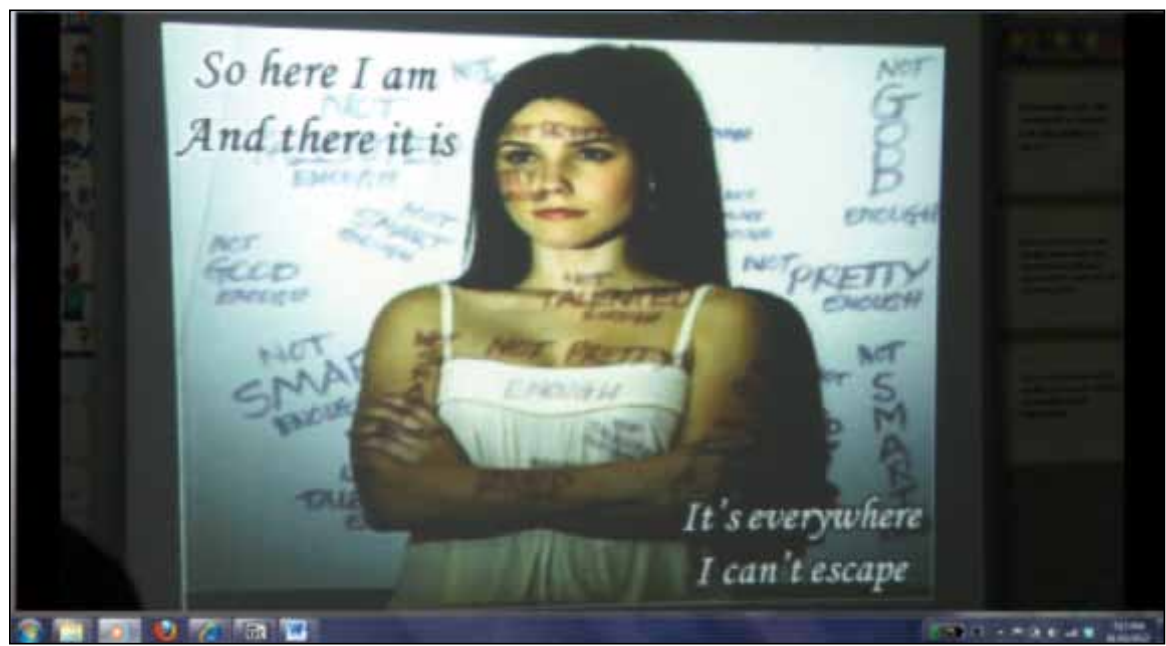

Fig. 4: Media messages are everywhere

Gigi explained,

It took me forever to find this picture and I was really happy when I found it. It felt like it was really good because ... it really goes with poem ... saying 'these are all the things she's saying about herself and how she gets labelled and a lot of the words are repeated which I think is also really good. You don't think 'I'm not pretty enough' and get on with it. When you think that it's something that goes through your mind every day and you think about it constantly. It's surrounding her because it doesn't just affect you in one place-it's everywhere and once you think it, you can't get it out of your head.

This image coincides nicely with Aguilera's lyrics, "Now and then I get insecure/From all the pain/I'm so ashamed ..." (Perry, 2002).

All of the girls in the images are different and Gigi explained that initially she had tried to edit the girls' appearances so that they all looked similar. But then, she explained, she decided that even though this was one girl's story, she wanted the girls to represent "a lot of different types of people, ages, showing that lots of people have to overcome and deal with these obstacles."

One of the most provocative images, shown in Figure 5, is of a young girl who has been made up to look like an adult model. The image is labeled to draw attention to the many unnatural alterations made to the child to get her ready for a beauty competition. 


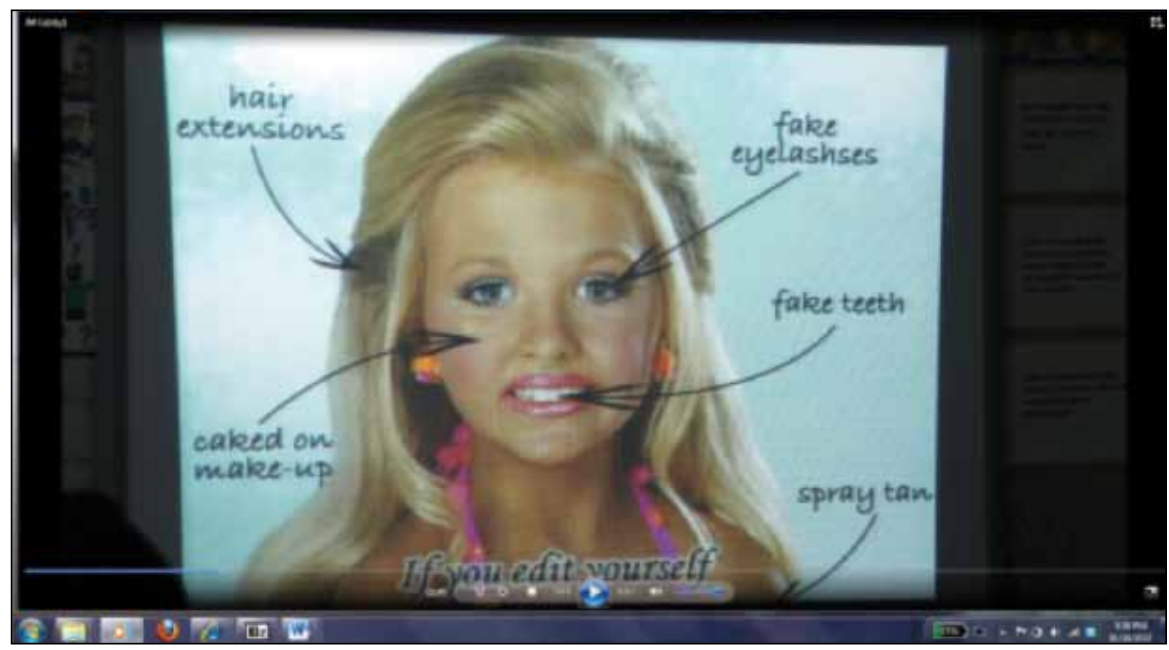

Fig. 5: "Fake little barbie dolls"

Gigi became quite angry as she explained that she chose this image to draw attention to the impact that negative media messages have on even very young children. Making a reference to the TV show "Toddlers \& Tiaras" she commented,

I've watched that show before and it's sickening to see how they act. Having a four-year old child saying facial beauty is the most important thing and if you're not beautiful then you can't win in life ... it's disgusting! So I really wanted to show that because I think it's important for people to understand that even if a kid says that they like being dressed up and pampered, that's not going to help them in the future ... when they can't always be like the fake little Barbie doll they won't feel confident in themselves.

Gigi's message, that girls should "love and be themselves," becomes clear by the end of the poem. In Figure 6, Gigi argues that "it's not okay" to try to be someone else, despite what your friends or peers expect. 


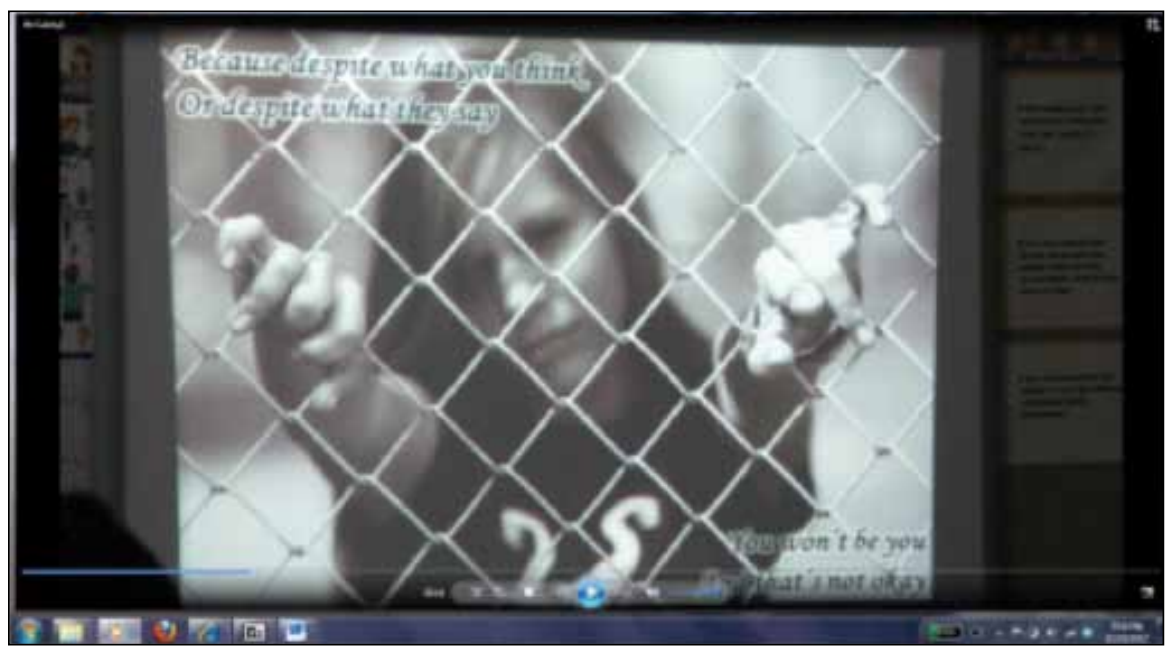

Fig. 6: She won't be you

Gigi's poem intentionally concludes in bright colours. In the final two slides (Figures 7 and 8), Gigi explained, "she looks confident. I put 'perfect' in a pink glow because I wanted to put emphasis on the positives. Some people can still manage to overcome all the negative media messages and this image gives us reassurance that it's possible." In the last image, Gigi uses a heart-shaped fingerprint and explained to the class, "everyone has a different fingerprint and this is a representation that everyone is different. Also the shape of a heart, which I liked because it's saying that not only do you love yourself but you love the fact that there is difference in the world."

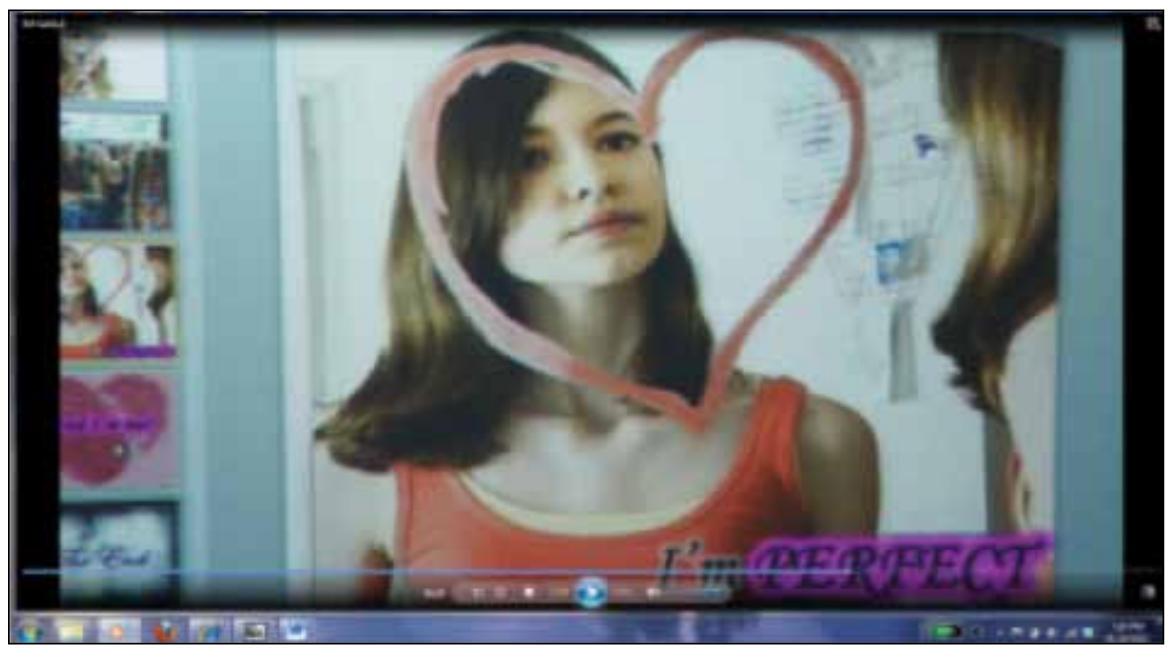

Fig. 7: Image of confidence 


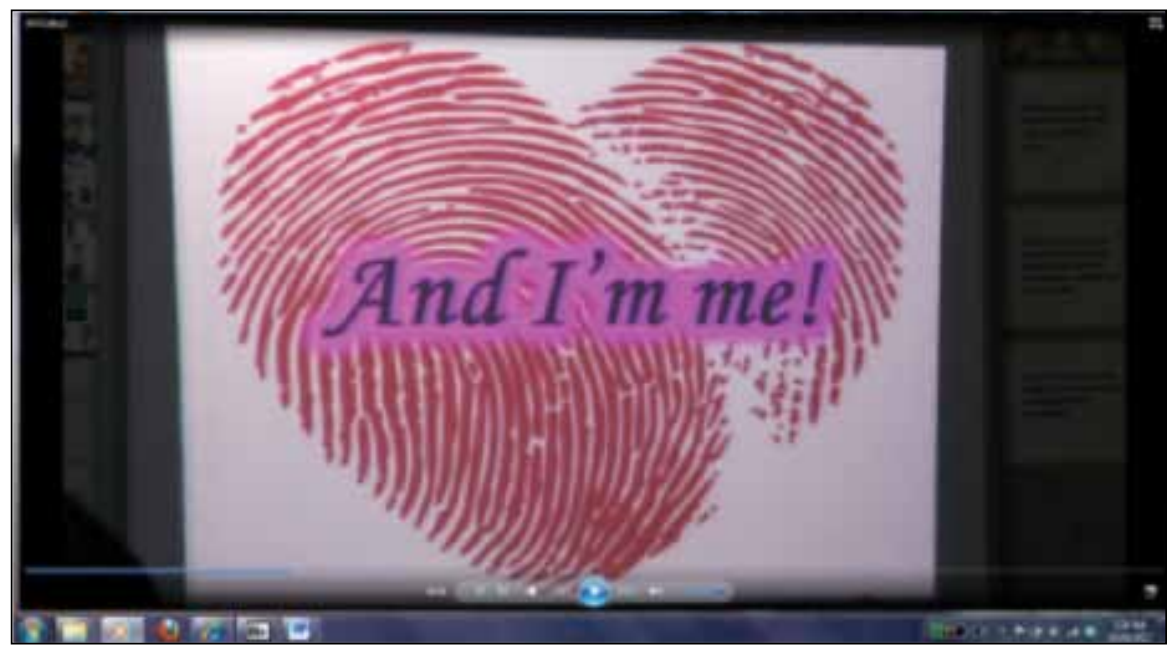

Fig. 8: Difference is good

Gigi's digital poem and her explanation of the design choices she made demonstrate evidence of critical thought, particularly of how the media manipulates its audience and how adolescents can and should resist the pressure to look and be a certain way.

\section{A Way Forward With Mediated Learning}

Different technologies impact the kinds of things our students can do, the meanings they can express, the relationships they can have, the thoughts they can think, and the social identities they can assume in particular situations. If we think about any technology, we will be able to determine what the constraints and affordances are: so, for example, one constraint of social networking tools is that we have to be particularly careful about privacy; but social networking tools enable us to connect with people all over the world in different ways, whether we are using Linkedln to build our work networks or whether we're using Pinterest to share projects or recipes with like-minded people. Although we outline some of the constraints and challenges we came up against below, we have chosen to focus on the affordances that the digital media offered the students in this research project.

Given their reliance on and their affinity for the use of technology in their out-of-school lives, it is not surprising that the students who participated in this 
research project demonstrated an increase in their level of engagement while using technology to access resources in their in-school lives. Although getting students more engaged through the use of digital media is an important benefit, they became proficient and critical users of the technologies, as well as proud producers of their own digital texts. By gaining access to both digital resources and the necessary technological tools with which to explore these resources, students were able to develop their knowledge and application skills, and to demonstrate these new skills by participating in collaborative activities on the social networking site, Ning, by deconstructing and reconstructing advertisements, and by creating their own original multimodal digital poetry. Over the course of the project, students were asked to think critically about the impact of digital technology and media on their lives, and to examine the underlying messages. The immersion of the students in the world of digital technology during their in-school lives exposed them to a wide variety of resources which they would not ordinarily have had the opportunity to explore in a traditional text-based classroom environment, and which clearly demonstrated the potential for the development of adolescents' digital literacies and identities.

From our experiences working with these students, we believe that to move forward with the integration of digital media, we need a new pedagogy, one that is inquiry based, focused on real-life problem solving, based on content that matters to adolescents, and one that allows them to express themselves through multiple means, anytime, anywhere. In this project we found the pairing of triedand-true "traditional" literacy activities such as literature circles with digital literacies that focused on accessing information and digital tools via the Internet and creating multimodal digital texts that promote awareness of an important adolescent issue very successful.

However, there were a number of challenges to overcome during this research project, not the least of which was ongoing accessibility issues and other barriers to implementation including time, resources, and support. At the inception of the project, the school's wireless technology was still in the early stages of implementation, and there were frequent, sporadic outages and long interruptions of service. Also, the school board's web filtering system initially restricted access to the Ning and it took several weeks to be unblocked. This led to a delay in the students being able to contribute their responses, and a resulting decline in their productivity. The devices themselves also had some limitations such as the lack of keyboard, sites requiring Flash, the inability for students to create presentations using Prezi or to use Tagxedo or Wordle, as well as other compatibility issues. Additionally, as the students came to the study with varying degrees of technological knowledge, some 
training on the devices as well as on how to navigate through the online resources was required. This was frustrating at times for the more proficient technophiles in the class, and led, in some instances, to some mild off-task behaviour. A few students required frequent monitoring, particularly when using their own devices; off-task behaviour was generally limited to the watching of YouTube videos and the playing of online games. Overall, as a group, the students embraced the project with great enthusiasm and came to rely upon both the devices and the access to technology as daily components of their in-school lives.

This project has led to future research examining the use of mobile devices in grades 6-10 classrooms in Ontario and in Newfoundland. In a 3-year federally funded project that began in September 2012, we are looking at the use of mobile devices to develop critical and digital literacy skills and to develop a guide for best practices in this area as school boards continue to equip their schools with WIFI.

\section{Notes}

1. This research is generously funded by the Ontario Ministry of Research and Innovation's Early Researcher's Award.

2. Ning is a private social networking platform that can be set up as a forum in which users exchange ideas, reflections, videos, images, and music files, and allows them to engage in an ongoing dialogue with one another. Personal profile pages are customized by the participants, much like Facebook. Content and the invitation of participants is controlled by the site's administrator in order to assure privacy and appropriateness of content.

\section{References}

Anderson, T. (2001). The hidden curriculum in distance education. Change Magazine, 33(6), 28-35.

Beach, R., Appleman, D., Hynds, S., \& Wilhelm, J. (2011). Teaching literature to adolescents. NY: Routledge.
Bruce, D. (2009). Reading and writing video: Media literacy and adolescents. In Handbook of Adolescent Literacy Research, L. Christenbury, R. Bomer and P. Smagorinsky, (Eds.). New York: The Guilford Press, 287-303. 
Bruner, J. (1994). Acts of meaning: Four lectures on mind and culture. Cambridge, MA: Harvard University Press.

Burn, A. (2008). The case of rebellion: Researching multimodal texts. In J. Coiro, M. Knobel, C. Lankshear \& D. Leu (Eds.) Handbook of Research on New Literacies. NY: Lawrence Erlbaum Associates, 151-178.

Connelly, F. M., \& Clandinin, D. J. (2006). Narrative inquiry. In J. Green, G. Camilli \& P. Elmore (Eds.), Handbook of complementary methods in education research (pp. 477-487). Mahwah, NJ: Lawrence Erlbaum.

Cope, B., \& Kalantzis, M. (Eds.). (2000). Multiliteracies: Literacy learning and the design of social futures. London: Routledge.

Gee, J. (2004). Situated language and learning: A critique of traditional schooling. New York: Routledge.

Harste, J. (2003). What do we mean by literacy now? Voices from the Middle, 10(3), Wilson Education Abstracts, 8-11.

Hull, G.A., \& Katz, M. (2006). Creating an agentive self: case studies of digital storytelling. Research in the Teaching of English, 41(1), 43-81.

Jewitt, C. (2008). Technology, literacy, learning: A multimodal approach. New York: Routledge.

Jones, R. H., \& Hafner, C. A. (2012). Understanding digital literacies: A practical introduction. Routledge, New York.

Kress, G., \& Van Leeuwen, T. (2001). Multimodal discourse: The modes and media of contemporary communication. New York: Oxford University Press.
Lankshear, C., \& Knobel, M. (2007). A new literacies sampler. New York: Peter Lang. New London Group. (1996). A pedagogy of multiliteracies: Designing social futures. Harvard Educational Review, 66(1), 60-92.

Perry, L. (2002). Beautiful. [Recorded by Christina Aguilera]. On Stripped [CD]. New York: RCA Corporation.

Selber, S. (2004). Multiliteracies for a digital age. Carbondale: Southern Illinois University Press.

Stake, R. (2000). Case studies. In Handbook of qualitative research, 2nd Ed. N. Denzin \& Y. Lincoln, Eds. Thousand Oaks, CA: Sage Publications, 435-454.

Strauss, A., \& Corbin, J. (1990). Basics of qualitative research: Grounded theory, procedures and techniques. Newbury Park: Sage Publications.

Weber, S., \& Mitchell, C. (2008). Imagining, keyboarding, and posting identities: Young people and new media technologies. In D. Buckingham (Ed.). Youth, Identity, and Digital Media, Cambridge: The MIT Press, 25-48.

Wenger, E. (1998). Communities of practice: Learning, meaning and identity. Boston: Cambridge University Press.

Wenger, E. (2000). Communities of practice and social learning systems. Organization, $7(2), 225-246$.

Wenger, E. (2007). Communities of practice. A brief introduction. Retrieved from http:// www.ewenger.com/theory/index.htm.

Wenger, E. (2009). Digital habitats: Stewarding technology for communities. Portland, OR: CPsquare. 


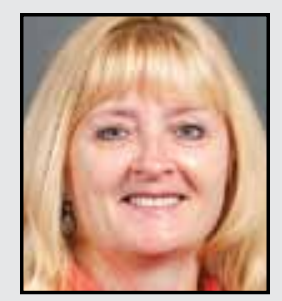

Janette Hughes is an Associate Professor at the Faculty of Education, University of Ontario Institute of Technology, where she teaches in the Preservice and Graduate Programs. Her research based on digital literacies uses multimodal, interactive media to open up new possibilities for exploration, writing, performance, and understanding. Dr. Hughes's research was recognized by the Ontario Ministry of Research and Innovation through an Early Researchers Award that will fund her work on digital literacies and social justice for three years.

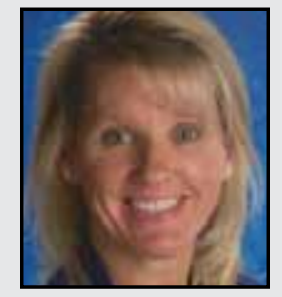

Stephanie Thompson teaches intermediate students at an Ontario elementary school and is also a graduate student at the University of Ontario Institute of Technology, where she is completing an M.A in Education in Digital Technologies. Her research interests include digital literacy, critical media literacy, and digital storytelling. She has been involved in several research projects centering on digital technology, and has explored the subjects of social justice, adolescent identities, bullying, and the effects of media on young adults with her students. Stephanie is the 2013 Canadian recipient of the International Reading Association's Technology in Reading Award. 